\title{
Storage of gastrointestinal endoscopes: when is the safe time for re-use?
}

\author{
Armazenamento de endoscópios gastrointestinais: qual o tempo seguro para o reúso?
}

Almacenamiento de endoscopios gastrointestinales: ¿cuál el tiempo seguro para la reutilización?

'Universidade Federal de Minas Gerais. Belo Horizonte, Minas Gerais, Brazil.

How to cite this article:

Garcia NB, Oliveira AC. Storage of gastrointestinal endoscopes: when is the safe time for re-use?.

Rev Bras Enferm. 2022;75(3):e20210216. https://doi.org/10.1590/0034-7167-2021-0216

\section{Corresponding author:}

Naiara Bussolotti Garcia

E-mail: bussolottin@gmail.com

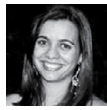

EDITOR IN CHIEF: Álvaro Sousa ASSOCIATE EDITOR: Ana Cristina Silva

Submission: $10-03-2020$

Approval: 10-13-2021

\section{ABSTRACT}

Objectives: to identify the safe storage time for the use of flexible gastrointestinal endoscopes after high-level disinfection, as well as the defining criteria for this time. Methods: an integrative literature review was carried out in the Virtual Health Library, PubMed, Scopus, and Web of Science, considering original articles published since 2000. Results: eleven articles were selected, whose storage times ranged from 1 to 56 days, with a predominance of one to seven days (73\%). Several criteria were used to define this time, predominantly the premise of efficient processing (100\%), use of alcohol flush (64\%), use of drying cabinets $(18 \%)$, among others. Conclusions: the criteria for determining the storage time did not show a consensus for clinical practice. Expanding the discussion of this theme with the definition of the minimum necessary conditions is of fundamental importance for the reduction of risks and safety of the procedure and the patient.

Descriptors: Endoscopes, Gastrointestinal; Disinfection; Equipment Contamination; Equipment Reuse; Patient Safety.

\section{RESUMO}

Objetivos: identificar o tempo de armazenamento seguro para utilização de endoscópios flexíveis gastrointestinais após a desinfecção de alto nível, bem como os critérios definidores desse tempo. Métodos: realizou-se uma revisão integrativa da literatura na Biblioteca Virtual em Saúde, PubMed, Scopus e Web of Science, considerando artigos originais publicados desde 2000. Resultados: foram selecionados 11 artigos, cujos tempos de armazenamento variaram entre 1 e 56 dias, com predomínio de um a sete dias (73\%). Utilizaram-se diversos critérios para definição desse tempo, sendo predominantes a premissa do processamento eficiente (100\%), uso de flush de álcool (64\%), uso de armários de secagem (18\%), entre outros. Conclusões: os critérios para determinação do tempo de armazenamento não evidenciaram um consenso para prática clínica. Ampliar a discussão dessa temática com definição das condições mínimas necessárias é de fundamental importância para a redução de riscos e segurança do procedimento e do paciente.

Descritores: Endoscópios; Desinfecção; Contaminação de Equipamentos; Armazenamento de Produtos; Segurança do Paciente.

\section{RESUMEN}

Objetivos: identificar el tiempo de almacenamiento seguro para utilización de endoscopios flexibles gastrointestinales después de la desinfección de alto nivel, así como los criterios definidores de ese tiempo. Métodos: realizado una revisión integrativa de la literatura en la Biblioteca Virtual en Salud, PubMed, Scopus y Web of Science, considerando artículos originales publicados desde 2000. Resultados: fueron seleccionados 11 artículos, cuyos tiempos de almacenamiento variaron entre 1 y 56 días, con predominio de uno a siete días (73\%). Utilizados diversos criterios para definición de ese tiempo, siendo predominantes la premisa del procesamiento eficiente (100\%), uso de flush de alcohol (64\%), armarios de secado (18\%), entre otros. Conclusiones: los criterios para determinación del tiempo de almacenamiento no evidenciaron un consenso para práctica clínica. Ampliar la discusión de esa temática con definición de las condiciones mínimas necesarias es de fundamental importancia para la reducción de riesgos y seguridad del procedimiento y del paciente. Descriptores: Endoscopios; Desinfección; Contaminación de Equipos; Almacenamiento de Productos; Seguridad del Paciente. 


\section{INTRODUCTION}

Gastrointestinal flexible endoscopes are equipment of complex structure and conformity, with channels of different angles, accesses, and lumens, which make friction difficult and, consequently, the removal of dirt and moisture. In this context, the maintenance of residues, moisture and microorganisms can favor both cross-contamination between patients undergoing endoscopic procedures and the formation of biofilms. These consist of a complex structure, composed of microorganisms adhered to an abiotic and biotic surface, protected by extracellular polysaccharide substances or exopolysaccharide matrix (EPS), which favors protection by preventing the action of antimicrobial agents ${ }^{(1-5)}$.

Infections related to such procedures, as well as the transmission of resistant microorganisms, mainly associated with contaminated duodenoscopes, have been described since 2010 in several countries in Europe and the United States of America, alerting world authorities, associations and gastroenterology societies about the weaknesses in complying with endoscope processing guidelines ${ }^{(6-11)}$. However, outbreaks have also occurred in healthcare facilities whose processing guidelines established by manufacturers and regulatory societies have been widely followed ${ }^{(8-9)}$.

Although the record of cross-transmission of microorganisms and outbreaks among patients undergoing endoscopic procedures occurs under adequate processing conditions, the predominance of cases has been reported in situations where failures or omissions in one or more of the steps have occurred; in addition, there is the challenge related to the design of endoscopes. The structure of the equipment associated with the multiple steps to be followed for cleaning and disinfection, among other factors, increase the difficulty in providing safe equipment for use ${ }^{(12)}$. As for the design, duodenoscopes increase cleaning challenges by the presence of an additional mechanism called "elevator channel"(12).

Furthermore, other variables can influence endoscope contamination, such as failure to dry and inadequate storage ${ }^{(13-14)}$. Maintaining moisture inside the canals favors the proliferation of residual microorganisms such as Pseudomonas aeruginosa, Klebsiella pneumoniae, among others ${ }^{(15-17)}$ and facilitates their transmission, especially in patients at greater risk of cross-contamination and infections by resistant microorganisms after endoscopic procedures $s^{(4,12-14)}$. In this sense, the definition of the safe time to use endoscopes after processing has been a major question in clinical practice, especially regarding patient safety, in order to mitigate the risk of cross-infection and outbreaks such as those occurring in several countries of the Europe and the United States ${ }^{(8-11)}$.

Another aspect to be highlighted, which constitutes an important knowledge gap, refers to the definition of criteria that provide subsidies for services to determine the safe interval between processing and use. This is mainly related to the inconsistencies and divergences about storage found in the international guidelines of the main societies, such as the type of cabinet or cupboard to be used and the use of alcohol flush in the canals. In addition to these factors, it appears that there is little evidence available on this definition of criteria, which provides for determining the time and conditions of safe storage to be adopted in the clinical practice of services ${ }^{(2,13-14)}$.

The theme and the evaluation of what studies have pointed to the determination of storage time are relevant, as a way to answer a question of the clinical routine of endoscopy services and to identify the maximum period considered as safe, in addition to the criteria that guarantee this process, subsidizing the practice. For all these reasons, it was decided to carry out an integrative literature review.

\section{OBJECTIVES}

To identify the safe storage time for using flexible gastrointestinal endoscopes after high-level disinfection, as well as the defining criteria for this time.

\section{METHODS}

\section{Ethical aspects}

The data used in the integrative review are in the public domain, so they do not need to be analyzed by the ethics committee.

\section{Study design, period and place}

This was an integrative literature review study, a tool that provides the synthesis of knowledge already produced, providing support for decision-making in clinical practice and identification of gaps demonstrating the need for further studies ${ }^{(18)}$. Based on the guidelines of the Preferred Reporting Items for Systematic Reviews and Meta-Analyses extension for Scoping Reviews (PRISMA-ScR) (18), the construction of this review followed six steps: identification of the theme and relevance (research question); establishment of inclusion and exclusion criteria; extracting information from studies; evaluation of included studies; interpretation of results; and presentation of the synthesis of knowledge.

To prepare the research question, the PICO strategy was adopted (acronym for Population/object, Intervention, Comparison and Outcome/outcome), in order to meet the scope ${ }^{(19)}$. It was considered P - Gastrointestinal endoscopes; I - Actions taken to ensure safe definition of shelf life; and O - Defined safe post-disinfection storage time.

In this sense, the following clinical practice question was delimited: "What is the safe time for storage (shelf time) of flexible gastrointestinal endoscopes after high-level chemical disinfection and what are the primary criteria used for its definition?" Based on this questioning, it was intended to understand how these defined times can be incorporated or followed in the daily life of services, in their different processing and storage conditions.

Searches were conducted on February 10, 2021, in the Virtual Health Library (VHL), Medical Literature Analysis and Retrieval System Online (PubMed), Scopus and Web of Science (WOS).

\section{Sample; inclusion and exclusion criteria}

The selection included original articles dealing with the processing of endoscopes with an emphasis on storage and storage time after high-level chemical disinfection until the next use, with an outcome determined by microbiological culture. As exclusion criteria, review articles were adopted, those that did not establish a controlled storage period after high-level disinfection or that did not perform any type of processing before storage, as well as those that used unusual processing in clinical practice, such as sterilization or another little-known innovative method. 


\section{Study protocol}

The following Health Science Descriptors (DeCS) and Medical Subject Headings (MeSH) were admitted: Endoscópios gastrointestinais; Endoscópios; Endoscopes; Endoscopes, gastrointestinal; and Duodenoscopes. They were combined by means of Boolean OR or AND operators with uncontrolled terms, based on the PCC (Population, Concept and Context) strategy, used to guide the search strategy, as it allows the use of descriptors considering ideas implicit in the research question ${ }^{(19)}$.

This culminated in the following search strategy: ("Gastrointestinal endoscope" or Endoscope or Duodenoscope) and ("Hang time" or "Shelf life" or Storage or "Shelf time") and (Dry or "Storage cabinet" or Cabinet or "High -level disinfection" or Processing or Reprocessing or Clean or Biofilm or Contamination or Microbial contamination). It was also translated into Portuguese and Spanish when the research was carried out in the VHL.

\section{Analysis of results and statistics}

Data analysis was performed with the aid of a specific instrument, prepared in an Excel spreadsheet, containing aspects related to the identification of articles, authors, year of publication, location, design, limitations, studied equipment, processing steps, used methodology and outcome.

As for the data related to processing, the records were analyzed according to the practices that could influence the safety of the storage and this step itself, such as solutions used in processing, drying the channels, performing a flush with $70 \%$ alcohol (ethyl or isopropyl), form of packaging the endoscope during storage and storage time after disinfection. In addition to these practices, we sought to identify the criteria used by the authors as requirements for determining safe storage time.

The search and selection were carried out by two reviewers independently, to read titles, abstracts and define those for full reading.

The quality of evidence was classified according to five of the six levels of evidence presented below, as all types of reviews were excluded from the sample ${ }^{(20)}$ : level 1, meta-analysis of multiple controlled studies; level 2, individual study with experimental design; level 3 , study with quasi-experimental design as a study without randomization with a single pre-test and post-test group, time series or case-control; level 4, study with non-experimental design as descriptive correlational and qualitative research or case studies; level 5 , case report or data obtained systematically, of verifiable quality or program evaluation data; level 6 , opinion of reputable authorities based on clinical competence or opinion of expert committees, including interpretations of information not based on research ${ }^{(20)}$.

\section{RESULTS}

From the initial search, 404 documents were selected and distributed as follows: 191 in PubMed, 79 in Scopus, 54 in VHL
Articles identified by data search $(\mathrm{N}=404)$

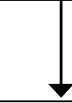

Articles after removal of duplicates $(n=339)$

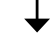
$(n=318)$

Articles excluded after complete reading: Editorial and letter to the reader $(n=2)$; They used sterilization and unconventional processing method $(n=3)$;

Did not specify minimum storage time $(n=1)$

Did not analyze storage $(n=1)$

Did not perform processing before storage $(n=3)$

Articles included in the study $(n=11)$

Figure 1 - Flowchart of the selection process of articles for sample composition, based on the PRISMA-SCR tool

and 80 in Web of Science. They were exported and organized in a Microsoft Excel software spreadsheet, in which the screening was carried out, excluding duplicate studies and others that, by reading the title and abstracts, were identified as not belonging to the scope of the search.

Articles selected for full reading were excluded when they did not meet the eligibility criteria, which resulted in a final sample of 11 articles, as shown in Figure 1.

The 11 studies that constituted the final review sample are distributed as follows: PubMed (5), BVS (2), Scopus (2) and Web of Science (2). They were carried out in the Czech Republic (1)(21), France (1)(22), Australia (2)(23-24), United States $(3)^{(25-27)}$ and Canada $(4)^{(4,28-30)}$. Regarding the level of evidence according to Stetler et al. ${ }^{(20)}, 18 \%{ }^{(22,30)}$ of the selected articles correspond to level 2 (experimental studies) and $82 \%^{(4,21,23-29)}$ to level 3 (time series).

It was found that about a third of the publications occurred between the years 2002 and 2007 (36\%) (21,23-24,28), but the predominance was from the period between 2008 and 2020 $(64 \%)^{(4,22,25-27,29-30)}$, characterized by a significant increase in cases of transmission of microorganisms by flexible endoscopes.

As a premise for maintaining the quality of processing in storage, $100 \%$ of the studies determined as essential the rigor in the phases that precede the storage/storage of the equipment.

As for the type of endoscope evaluated in the studies, duodenoscopes, colonoscopes and gastroscopes stood out $(6)^{(4,21-22,26-27,29)}$.

The use of automated equipment in cleaning/disinfection was reported by most of the analyzed studies (10) ${ }^{(21-30)}$, and only one study $(1)^{(4)}$ did not mention whether the liquid chemical cleaning and disinfection used was manual or automated. 
As for high-level disinfection with chemical solution, the use of glutaraldehyde $(37 \%)^{(23,25,27-28)}$, orthophthalaldehyde $(18 \%)^{(21,26)}$, and peracetic acid $(18 \%)$ were reported ${ }^{(22,24)}$, and the others $(27 \%)^{(4,29-30)}$ did not present the specification of the solution used.

In most (73\%) $)^{(21-23,25,27-30)}$ of the articles analyzed, drying was performed by injecting air into the channels, using both automated and manual equipment. Two authors reported the time of exposure to the air injected into the canals being ten ${ }^{(29)}$ and three ${ }^{(28)}$ minutes. The drying phase ${ }^{(4,26)}$ was not described by $18 \%$, and the other $9 \%$ reported vertical drying by gravity for five minutes ${ }^{(24)}$.

Performing an alcohol flush to aid in drying was a practice reported in 64\% ${ }^{(23-25,27-30)}$ of the analyzed studies.

Storage in cabinets/drying cabinets with ventilation and humidity control was reported in $18 \%$ of the studies ${ }^{(22,30)}$; and $73 \%$ used conventional dust-free and naturally ventilated models $^{(4,21,23-24,26-29)}$. One of them also used non-ventilated cabinets ${ }^{(26)}$; and the remaining $9 \%$, hooks in a room dedicated to the storage of temperature and humidity controlled endoscopes ${ }^{(25)}$.
The use of conventional cabinets was not characterized in studies regarding structural conditions, and only one article described the frequency of cleaning ${ }^{(29)}$.

The positioning of the endoscope during storage was described vertically in $64 \%$ of the studies ${ }^{(21,23-27,30)}$; horizontally, according to the validation of the cabinet manufacturer ${ }^{(22)}$, in $9 \%$; and the other $27 \%$ did not mention details about their position while on guard ${ }^{(4,28-29)}$.

Only $25 \%$ of those who did not use drying cabinets (2/8) mentioned the importance of removing the valves during equipment storage to avoid internal humidity and fluid retention in the channels $s^{(24,27)}$.

The performance of endoscope processing by trained and trained personnel was described as a fundamental safety criterion for the entire process, mentioned by $36 \%$ of the authors, reaffirming the qualification as an essential condition for the execution of processing recommendations ${ }^{(22-24,27)}$.

Chart 1 summarizes the synthesis of the articles analyzed with the retention time suggested by the authors.

Chart 1 - Summary chart of studies $(n=11)$ regarding storage time of flexible gastrointestinal endoscopes, 2002-2021

\begin{tabular}{|c|c|c|c|c|}
\hline $\begin{array}{l}\text { Reference } \\
\text { Outline Level of } \\
\text { Evidence }\end{array}$ & $\begin{array}{l}\text { Types of } \\
\text { Endoscopes } \\
\text { Sample Size }\end{array}$ & $\begin{array}{l}\text { Criteria adopted to } \\
\text { define shelf life }\end{array}$ & Outcomes & $\begin{array}{l}\text { Suggested } \\
\text { storage } \\
\text { time }\end{array}$ \\
\hline $\begin{array}{l}\text { Riley et al. }{ }^{(24)} \\
2002, \\
\text { Prospective } \\
\text { observational } \\
\text { Level } 3\end{array}$ & $\begin{array}{l}1 \text { colonoscope } \\
30 \text { samples }\end{array}$ & $\begin{array}{l}\text { Bacterial growth: } \\
\text { Up to } 5 \text { CFU/ml - } \\
\text { acceptable; } \\
5-20 \text { CFU/ml moderate; } \\
>20 \mathrm{CFU} / \mathrm{ml} \mathrm{high.}\end{array}$ & $\begin{array}{l}\text { Within } 24 \text { hours of storage, there was no microbiological growth. } \\
\text { In } 168 \text { hours, there was growth in two samples of } 1 \mathrm{CFU} / \\
\mathrm{ml} \text { of coagulase negative Staphylococcus and } 1 \mathrm{CFU} / \mathrm{ml} \text { of } \\
\text { Micrococcus sp. }\end{array}$ & 7 days \\
\hline $\begin{array}{l}\text { Rejchrt et al. }{ }^{(21)} \\
2004, \\
\text { Prospective } \\
\text { observational } \\
\text { Level } 3\end{array}$ & $\begin{array}{l}10 \text { endoscopes } \\
\text { (gastroscope, } \\
\text { duodenoscope and } \\
\text { colonoscope) } \\
\text { Total of } 135 \text { samples }\end{array}$ & $\begin{array}{l}\text { Acceptable } \\
\text { microbiological } \\
\text { growth of commensal } \\
\text { microorganisms }\end{array}$ & $\begin{array}{l}\text { Positive culture: } 3 \% \text {. } \\
\text { Corynebacterium pseudodiphteriae (2nd day) } \\
\text { Staphylococcus epidermidis ( } 2 \text { nd and } 3 \text { rd day at two different } \\
\text { points) } \\
\text { He did not mention the amount of colony forming units found. }\end{array}$ & 5 days \\
\hline $\begin{array}{l}\text { Osborne et al. }{ }^{(23)} \\
2007, \\
\text { Prospective } \\
\text { observational } \\
\text { Level } 3\end{array}$ & $\begin{array}{l}23 \text { endoscopes } \\
\text { Total of } 194 \text { samples } \\
\text { Gastroscope, } 101 \\
\text { Echoendoscope, } 8 \\
\text { Colonoscope, } 74 \\
\text { Duodenoscope, } 11\end{array}$ & $\begin{array}{l}\text { Acceptable } \\
\text { microbiological growth of } \\
\text { microorganisms without } \\
\text { clinical importance }\end{array}$ & $\begin{array}{l}\text { Overall contamination rate: } 15.5 \% \text {. } \\
\text { Coagulase-negative Staphylococcus and Micrococcus were the } \\
\text { most common microorganisms ( } 6.7 \% \text { and } 3.1 \%) \text {. } \\
\text { Bacillus, Corynebacterium, fungus, Streptomyces ( } n=29) \\
12.9 \% \text { - } 1 \text { st day } \\
10 \% \text { - Between } 1 \text { st and } 2 \text { nd day } \\
17.2 \% \text { - Between } 2 \text { nd and 3rd day } \\
25 \% \text { - Between 3rd and 4th day } \\
37.5 \% \text { - Between } 6 \text { th and } 7 \text { th day } \\
\text { Yeast between the } 5 \text { th and } 6 \text { th day of storage }\end{array}$ & 5 days \\
\hline $\begin{array}{l}\text { Vergis et al. }{ }^{(28)} \\
2007, \\
\text { Multiphase } \\
\text { observational } \\
\text { Level } 3\end{array}$ & $\begin{array}{l}4 \text { duodenoscopes } \\
\text { and } 3 \text { colonoscopes } \\
\text { Phase } 1 \text { and } 2 \\
70 \text { samples } \\
\text { Stage } 3 \\
14 \text { samples }\end{array}$ & $\begin{array}{l}\text { Acceptable culture of } \\
\text { microorganisms of no } \\
\text { clinical importance; did } \\
\text { not detail the types. }\end{array}$ & $\begin{array}{l}\text { Phase } 1:(6 / 70) \text { positive culture ranging from } 10 \text { to } 200 \text { CFU/ml. } \\
\text { Predominant growth in the first } 5 \text { days. } \\
\text { Phase 2: No growth } \\
\text { Phase 3: Sample collection in } 24 \text { hours and } 7 \text { days } \\
\text { Positive culture on the } 7 \text { th day - } 700 \text { CFU/ml. } \\
\text { All positive cultures recovered Staphylococcus epidermidis. }\end{array}$ & 7 days \\
\hline $\begin{array}{l}\text { Alfa et al. }{ }^{(4)} 2012, \\
\text { Prospective } \\
\text { Level } 3\end{array}$ & $\begin{array}{l}5 \text { gastroscopes } \\
9 \text { colonoscopes } \\
6 \text { duodenoscopes } \\
\text { Total of } 383 \text { samples }\end{array}$ & $\begin{array}{l}\text { Acceptable } \\
\text { microbiological growth }< \\
200 \text { CFU/ml }\end{array}$ & $\begin{array}{l}\text { 5.7\% (22/383) contaminated samples after } 48 \text { hours: } \\
\text { (9/22) Bacillus gram-positive } 10 \text { CFU/ml; } \\
\text { (11/22) Gram-positive Coccus: Highest microbiological load found } \\
\text { 170 CFU/ml. } \\
(1 / 22) \text { Gram-negative Bacillus Pseudomonas luteola } 10 \mathrm{CFU} / \mathrm{ml} \text {; } \\
(1 / 22) \text { Fungi } 10 \mathrm{CFU} / \mathrm{ml} \text {; }\end{array}$ & 2 days \\
\hline
\end{tabular}




\begin{tabular}{|c|c|c|c|c|}
\hline $\begin{array}{l}\text { Reference } \\
\text { Outline Level of } \\
\text { Evidence }\end{array}$ & $\begin{array}{l}\text { Types of } \\
\text { Endoscopes } \\
\text { Sample Size }\end{array}$ & $\begin{array}{l}\text { Criteria adopted to } \\
\text { define shelf life }\end{array}$ & Outcomes & $\begin{array}{l}\text { Suggested } \\
\text { storage } \\
\text { time }\end{array}$ \\
\hline $\begin{array}{l}\text { Ingram et al. } \\
2013 \text {, } \\
\text { Longitudinal } \\
\text { prospective } \\
\text { Level } 3\end{array}$ & $\begin{array}{l}4 \text { colonoscopes } \\
\text { Total of } 32 \text { samples }\end{array}$ & $\begin{array}{l}\text { Clinically important } \\
\text { microorganism growth*** }\end{array}$ & $\begin{array}{l}\text { Recovery of Staphylococcus epidermidis and Staphylococcus } \\
\text { hominis with a maximum of } 2 \text { CFU/ml in two samples collected on } \\
\text { the } 14 \text { th day of storage. } \\
\text { And recovery of } \leq 1 \text { CFU } / \mathrm{ml} \text { of Staphylococcus epidermidis on the } \\
42 \text { nd day. }\end{array}$ & 56 days \\
\hline $\begin{array}{l}\text { Grandval et al..22) } \\
\text { 2013, } \\
\text { Experimental } \\
\text { Level } 2\end{array}$ & $\begin{array}{l}10 \text { gastroscopes } \\
11 \text { colonoscopes } \\
4 \text { duodenoscopes } \\
41 \text { samples for each } \\
\text { type of storage }\end{array}$ & $\begin{array}{l}<5 \mathrm{CFU} / \mathrm{ml} \text { (acceptable } \\
\text { level) } \\
\text { between } 5 \text { and } 25 \mathrm{CFU} / \mathrm{ml} \\
\text { (alert level) } \\
>25 \mathrm{CFU} / \mathrm{ml} \\
\text { or growth of any } \\
\text { potentially pathogenic } \\
\text { microorganism** } \\
\text { (action level) }\end{array}$ & $\begin{array}{l}\text { Drying cabinet: } \\
56.1 \% \text { without contamination } \\
43.9 \%<5 \text { CFU/ml Coagulase-negative Staphylococcus, } \\
\text { Micrococcus sp., Bacillus sp. } \\
\text { Conventional closet: } \\
41.4 \% \text { without contamination } \\
46.8 \%<5 \text { CFU/ml } \\
5 \% \text { between } 5 \text { and } 25 \mathrm{CFU} / \mathrm{ml} \text { Coagulase-negative Staphylococcus, } \\
\text { Micrococcus sp., Bacillus sp. ( } 6 \text { and } 7 \text { CFU/ml) } \\
7 \%>150 \text { CFU/ml Strenotrophomonas Maltophilia, Enterobacter } \\
\text { cloacae and Serratia odorifera }\end{array}$ & 3 days \\
\hline $\begin{array}{l}\text { Brock et al. } \\
2015, \\
\text { Prospective } \\
\text { observational } \\
\text { Level } 3\end{array}$ & $\begin{array}{l}4 \text { duodenoscopes } \\
4 \text { colonoscopes } \\
2 \text { gastroscopes } \\
\text { Total of } 96 \text { samples }\end{array}$ & $\begin{array}{l}\text { Growth } \leq 100 \text { colony } \\
\text { forming units (CFU)/ml }\end{array}$ & $\begin{array}{l}\text { Global contamination rate: } 29.2 \% \\
\text { Cultures: Coagulase-negative Staphylococcus, Micrococcus, Bacillus } \\
\text { Corynebacterium and Propionibacterium acnes. } \\
\text { Maximum of } 49 \text { CFU/ml } \\
\text { Microorganisms with pathogenic potential: Aureobasidium } \\
\text { pullulans (1st day); Enterococcus (7th day); a-hemolitic } \\
\text { Streptococcus (14th day); Candida parapsilosis (day } 21 \text { ) } \\
\text { All with growth } \leq 1 \mathrm{CFU} / \mathrm{ml}\end{array}$ & 21 days \\
\hline $\begin{array}{l}\text { Scanlon et al. }{ }^{(26)} \\
2017, \\
\text { Transverse } \\
\text { Level } 3\end{array}$ & $\begin{array}{l}6 \text { gastroscopes } \\
2 \text { duodenoscope } \\
1 \text { colonoscope } \\
\\
\text { Phase } 1 \\
27 \text { samples } \\
\text { Level } 2 \\
131 \text { samples }\end{array}$ & $\begin{array}{l}\text { Microbiological growth } \leq \\
100 \mathrm{CFU} / \mathrm{ml}\end{array}$ & $\begin{array}{l}\text { Phase } 1 \text { - Positive cultures: } 11.1 \% \text {. All } \leq 100 \mathrm{CFU} / \mathrm{ml} \text {. } \\
\text { Coagulase-negative Staphylococcus (On the } 69 \text { th and } 85 \text { th day of } \\
\text { storage) } \\
\text { Micrococcus (69th day of storage) } \\
\text { Phase } 2 \text { - Positive cultures: } 5.3 \% \text {. All } \leq 100 \mathrm{CFU} / \mathrm{ml} \text {. } \\
\text { Coagulase-negative Staphylococcus (7th, } 14 \text { th, } 28 \mathrm{th}, 42 \mathrm{nd} \text { day of } \\
\text { storage) } \\
\text { Neisseria subflava (28th day of storage) } \\
\text { Bacillus species (42nd and } 56 \text { th day of storage) } \\
\text { Viridans group streptococci (28th day of storage) } \\
\text { Candida albicans growth: } 10 \text { CFU/ml on the } 14 \text { th day of storage. }\end{array}$ & 56 days \\
\hline $\begin{array}{l}\text { Singh et al. }{ }^{(30)} \\
2018, \\
\text { Experimental } \\
\text { Level } 2\end{array}$ & $\begin{array}{l}3 \text { duodenoscopes } \\
\text { Total of } 119 \text { samples }\end{array}$ & $\begin{array}{l}\text { Any growth of Escherichia } \\
\text { coli or Enterococcus } \\
\text { faecalis and/or } \geq 100 \\
\text { CFU/ml of any other } \\
\text { microorganism is not } \\
\text { acceptable. } \\
\text { Inoculated suspension } \\
\text { of E. Coli and E. faecallis } \\
\text { at an approximate } \\
\text { concentration of } 108 \\
\text { CFU/ml before applying } \\
\text { the designed protocols. }\end{array}$ & $\begin{array}{l}\text { Protocol } 1 \text { - Cleaning and disinfection without alcohol flush }(\mathrm{n}=69) \\
\text { Enterococcus faecalis } \\
<9 \text { CFU/ml }-17 \text { samples } \\
10-99 \text { CFU/ml }-20 \text { samples } \\
\geq 100 \text { CFU/ml }-5 \text { samples } \\
\text { Other microorganisms } \\
\geq 100 \text { CFU/ml - } 9 \text { samples } \\
\text { Protocol } 2 \text { - Cleaning and disinfection followed by an alcohol flush } \\
\text { ( } n=20) \\
\text { Enterococcus faecalis } \\
<9 \text { CFU/ml }-4 \text { samples } \\
10-99 \text { CFU/ml }-7 \text { samples } \\
\geq 100 \text { CFU/ml }-4 \text { samples } \\
\text { Other microorganisms } \\
\geq 100 \text { CFU/ml }-1 \text { samples } \\
\text { Protocol } 3 \text { - Cleaning + extra cleaning and disinfection without } \\
\text { alcohol flush ( } n=30 \text { ) } \\
\text { Enterococcus faecalis } \\
<9 \text { CFU/ml }-6 \text { samples } \\
10-99 \text { CFU/ml }-13 \text { samples } \\
\geq 100 \text { CFU/ml }-2 \text { samples } \\
\text { Other microorganisms } \\
\geq 100 \text { CFU/ml - } 9 \text { samples } \\
\text { Other microorganisms identified in duodenoscopes were: } \\
\text { Bacillus spp., Paenibacillus spp., Brevibacillus spp., Neisseria spp., } \\
\text { Streptococcus spp. and Kocuria spp. }\end{array}$ & 1 a 3 days \\
\hline
\end{tabular}


Chart 1 (concluded)

\begin{tabular}{|c|c|c|c|c|}
\hline $\begin{array}{l}\text { Reference } \\
\text { Outline Level of } \\
\text { Evidence }\end{array}$ & $\begin{array}{l}\text { Types of } \\
\text { Endoscopes } \\
\text { Sample Size }\end{array}$ & $\begin{array}{l}\text { Criteria adopted to } \\
\text { define shelf life }\end{array}$ & Outcomes & $\begin{array}{l}\text { Suggested } \\
\text { storage } \\
\text { time }\end{array}$ \\
\hline $\begin{array}{l}\text { Mallete et al. }{ }^{(29)} \\
2018, \\
\text { Prospective } \\
\text { observational } \\
\text { Level } 3\end{array}$ & $\begin{array}{l}19 \text { gastroscopes } 24 \\
\text { colonoscopes } \\
5 \text { duodenoscopes } \\
\text { Total of } 164 \text { samples }\end{array}$ & $\begin{array}{l}\text { Microbiological results } \\
\text { below } 200 \text { CFU } / \mathrm{ml} \text {. }\end{array}$ & $\begin{array}{l}\text { There was no growth }>200 \text { CFU/ml within } 7 \text { days. } \\
\text { Type of microorganism not evaluated. } \\
\text { There was no description of all growths per day of storage. } \\
18 \text { contaminated samples. } \\
80 \text { CFU/ml (highest microbiological load found). } \\
\text { There was no significant difference comparing the microbiological } \\
\text { growth from 1,2,3,4,5,6 days to } 7 \text { days. }\end{array}$ & 7 days \\
\hline
\end{tabular}

**Staphylococcus aureus, Enterobacteriaceae, Pseudomonas sp., Stenotrophomonas maltophilia, Acinetobacter sp., Candida sp; ***Escherichia coli, Klebsiella Pneumoniae, Alpha streptococcus, Streptococcus pneumonia, Enterococcus, Klebsiella oxytoca.

The number of samples collected by the researchers varied according to the determination of the frequency of collection and the locations for the removal of these samples in the endoscopes, since such equipment has different lumens and peculiar structures.

The microbiological culture used as an outcome by the articles presented divergent methods to determine the maximum storage time, such as the incubation period for analysis of bacteriological growth, which ranged from 24 to 48 hours in $6^{(4,21,24-25,28-29)}$ of the 11 studies; another 2 used 72 hours ${ }^{(23,30)} ; 2^{(22,26)}, 5$ hours; and $1^{(27)}, 7$ days in diversified culture media. For the evaluation of fungal growth on sabouraud agar, two authors incubated for five days ${ }^{(4,26)}$ and one for seven days ${ }^{(27)}$; the other eight articles did not use this specific medium.

As for the storage time defined as safe to use the equipment after disinfection, $27 \% \%^{(4,22,30)}$ of the articles suggested a maximum storage time of 3 days, $46 \%{ }^{(21,23-24,28-29)}$, between 5 and 7 days; $27 \%{ }^{(25-27)}$, over 8 days, with a variation for 15,21 and 56 days.

Along with the analysis of the articles, a survey of the recommendations of societies and regulatory bodies in gastroenterology on the subject was carried out. In a total of ten documents evaluated, it was found that four institutions determine maximum storage time: Gastroenterological Nurses College of Australia and Gastroenterological Society of Australia (GENCA and GESA) ${ }^{(31)}$ up to 72 hours, depending on the type of equipment; Society of Gastroenterology Nurses and Associates (SGNA) ${ }^{(32)}$, up to seven days; in the British Society of Gastroenterology (BSG) ${ }^{(33)}$, the time can vary between 72 hours and 31 days according to the quality validation guaranteed by the cabinet manufacturer; Public Health Agency of Canada (PHAC) ${ }^{(34)}$, up to seven days. Others recommend a thorough evaluation of the reality of the processing performed and criteria for its validation to determine a maximum storage time, such as European Society of Gastroenterology and Endoscopy Nurses and Associates (ESGE-ESGENA) ${ }^{(3)}$, Association of periOperative Registered Nurses (AORN $)^{(36)}$ and Multisociety guideline on reprocessing flexible $\mathrm{Gl}$ endoscopes and accessories $^{(2)}$. These data were not included in the analysis conducted but used for the purpose of comparing the definitions found in the articles with the guidelines described.

\section{DISCUSSION}

Adverse events related to the use of endoscopes have been widely discussed around the world. In this sense, the Emergency Care Research Institute (ECRI), a North American non-profit institute that evaluates medical practices and products, has published annually the risks related to the use of health technologies, being uninterrupted (between 2011 and 2019) described the failures in the processing of endoscopes among the ten greatest concerns for patient safety. In 2019, specifically, the concern with the processing of endoscopes highlighted the risk related to their storage, understanding that the problems are not restricted to the cleaning and disinfection process as a guarantee of safe use for the patient ${ }^{(37)}$.

This analysis was certainly strengthened by the outbreaks recorded from $2010^{(8-11)}$, both in Europe and in the United States; and, as a result of these contaminations, an increase in the number of publications on the subject can be evidenced as a priority for researchers, aiming to maintain the quality of processing performed in endoscopy services ${ }^{(14)}$.

During their use, endoscopes are exposed to large amounts of contaminants, which, associated with their complex structure and processing difficulty, represent a greater possibility of retaining debris and moisture. Thus, it is possible to infer the presence of microorganisms in their internal structures, which cannot be accessed for friction, a fact that can contribute to the permanence of dirt and residues, favoring the formation of biofilm, one of the biggest challenges for processing safety ${ }^{(38)}$.

Entebacteriaceae, Pseudomonas aeruginosa and Salmonella are bacteria commonly related to exogenous contamination after gastrointestinal endoscopy procedures described in the literature, and their transmission is usually associated with failures in the equipment processing steps. In this context, Pseudomonas aeruginosa stands out, a gram-negative pathogen with positive tropism for humid environments, such as a water reservoir and flexible endoscope channels. It is also characterized by its ease in forming biofilms; it has structures that are difficult to remove and have great potential for transmission, especially in immunocompromised patients, as they are at greater risk of developing infections ${ }^{(38-40)}$.

Among the criteria presented in the articles, although the recommendation for efficient processing is described, few articles mentioned the need for a trained team to carry out the processing. However, studies suggest that training associated with the assessment of techniques performed regularly are essential tools for adherence to the processing steps, as well as for individual protection actions and prevention of pathogen transmission ${ }^{(41-42)}$.

Another point is that automated cleaning, disinfection, and drying equipment was widely used; they are technologies that allow less human interference in the processes, which favors the execution of the processing within the established standards. 
However, in emerging countries, this procedure is limited, as it involves investments, and the costs versus the potential benefits for greater safety and quality are not always considered ${ }^{(38,43)}$.

Inadequate drying of endoscopes was attributed as a possible cause of contamination in patients undergoing endoscopic procedures, and is therefore considered an extremely important phase in the processing of these equipment. Despite the strong recommendation on the rigor to be adopted at this stage, it appears that it has been neglected ${ }^{(13,15,43)}$.

The recommendations for forced air drying of the endoscope channels have not been detailed by the studies and guidelines as to the minimum execution time or how it can be validated in relation to its effectiveness. Barakat $(2019)^{(44)}$ proposes a minimum time of ten minutes as an effective way of drying. Even with the automated drying process, with time and air flow validated by processor washer manufacturers, they often do not promote the effective drying of endoscopes, as suggested in several works ${ }^{(13,43-44)}$.

Given the difficulty of internally inspecting the channels to verify the presence of moisture, residues and structural changes in the endoscopes, the equipment called "video borescope" has been indicated for this purpose, as it allows, through cameras, to capture internal images. In this sense, a more refined inspection is possible with identification of the effectiveness of drying performed in clinical practice and the visualization of other changes such as minor damage (cracks, scratches, discolorations, perforations) or residues that can contribute as a favorable environment to be a reservoir of microorganisms ${ }^{(13,44-46)}$. However, despite its great utility and incorporation as a technology in endoscopy services, cost is seen as an important obstacle to its adoption, especially in Brazil, where resources are scarce.

In this context, it is important to consider relevant aspects associated with the benefit of using the video borescope, in order to enable adherence to this practice, especially in services with a reduced number of equipment. These, used continuously, make it difficult to perform routine monitoring tests such as the leak test. In addition, they cause greater pressure on employees in carrying out the processing steps, increasing the occurrence of failures, especially in the drying step, since moisture represents a risk during storage $\mathrm{e}^{(5,44-46)}$.

Another activity used to reduce internal moisture in the endoscope channels is the removal of valves from the endoscope channels in the storage phase. The presence of occlusion of the channels prevents air circulation within them. Thus, when positioned vertically in conventional cabinets, it facilitates the drainage and evaporation of fluids accelerated by gravity, providing an unfavorable environment for microbiological growth ${ }^{(2,7,32-33,35-36)}$.

Also with regard to drying, rinsing with $70 \%$ ethyl or isopropyl alcohol associated with forced air in the endoscope channels was a practice carried out by some authors, with the purpose of facilitating evaporation and thus improving the effectiveness of the phase. However, due to the protein-fixing property of alcohol, this practice is contraindicated in Europe, to minimize the possibility of protein adhesion in the equipment channels, culminating in the formation of biofilms. Furthermore, this method holds the risk of transmission of Creutzfeldt-Jakob disease, a subacute spongiform encephalopathy whose etiology is attributed to the prion, an infectious agent formed by highly stable and resistant proteins, making the disease to be transmitted iatrogenically, by means of contaminated medical instruments $s^{(33,35,47)}$.

The increase in protein residues caused by the fixation of alcohol provides difficulty in the cleaning process and generates protection for microorganisms, facilitating the formation of biofilm, which directly interferes with the success of disinfection, increasing the risks of contamination ${ }^{(38,47)}$.

In addition, Singh $(2018)^{(30)}$ found that there was no improvement in the results of microbiological cultures with the insertion of an alcohol flush during processing, nor did they perform double cleaning, suggesting that the use of these steps does not add value to the final safety of the processing ${ }^{(30,47)}$.

Drying cabinets with filters, ventilation and humidity control were used in two articles analyzed and presented superior results when compared to conventional cabinets ${ }^{(22,30)}$. They are strongly recommended in Europe and Australia although they are not mandatory ${ }^{(31,35)}$. In the United States, drying cabinets do not have a broad indication for use, under the justification of low scientific production on the subject and little evidence about the improvement in the quality of processing with the use of these types of cabinets, although comparative studies point to a better maintenance of the quality of the process performed ${ }^{(2,5)}$.

Among studies comparing conventional cabinets with drying cabinets, Perambuil (2019) ${ }^{(48)}$ showed promising results with the use of drying cabinets. Equipment stored after being inoculated with Pseudomonas aeruginosa with $3.5 \log 10$ showed growth of up to 7 logs when stored for 24 hours in conventional cabinets; and reduction to less than 1 log when stored for two hours in drying cabinets.

Finally, regarding the safe time limit for storing endoscopes before the next use, most authors ${ }^{(4,21-24,28-30)}$ define a period between two and seven days of storage. Others showed safety for longer periods of up to 56 days ${ }^{(25-27)}$. However, they did not show uniformity in the practical criteria for processing and validating this interval.

The method used in the microbiological culture of the selected articles presented important divergent points, such as in the material collection patterns, acceptance criteria and analysis of results, as well as in the culture time for microbiological growth, factors that can influence the difference and the recovery of viable microorganisms ${ }^{(5,26,29)}$.

Routine microbiological monitoring in clinical practice, considered valid to detect processing failures, is not a consensus among gastroenterology societies ${ }^{(2,31-32)}$. Those that do not recommend it are based on issues about operationalization, such as standard, training of personnel for collection, need for quarantine of equipment until sample results, specialized laboratory network, periodicity, levels of acceptance of the recovery of microorganisms and analysis of the results. Such issues are still not well defined by most guidelines or the scientific community ${ }^{(2,32,49)}$.

One study compared two culture methods for assessing duodenoscope contamination and found an approximate $65 \%$ recovery rate with a detection limit of $10 \mathrm{CFU} / \mathrm{ml}$. It was demonstrated that, despite being an important tool to evaluate the processing, equipment may remain with microorganisms below the detection limit and present a satisfactory result, putting the patients at risk ${ }^{(50)}$. Therefore, microbiological culture should not 
be the only method to assess processing; other tools, ongoing audits and training, as well as post-procedure follow-up, can be useful as a method for quality analysis ${ }^{(50)}$.

In the United States, despite not being a routine recommendation, the CDC assesses, as factors for not indicating these cultures in daily life, the absence of well-defined methodologies, which leads to the risk of false-negative results. To avoid this risk, a methodological standard for sample collection was proposed, aiming to minimize potential unreliable results associated with high costs ${ }^{(49)}$.

With regard to the interpretation of results, there is also an important divergence in the studies, as some authors ${ }^{(4,29)}$ consider microbiological growth above 200 CFU as critical; while others, above 100 UFC $^{(26-27,30)}$; and certain authors, even above 20 UFC $^{(22,24)}$. Some considered the clinical importance of the type of microorganism found, and others did not. This divergence is also evidenced by the guidelines found in the guidelines. For example, the CDC establishes action levels when "high concern" microorganisms appear in crops greater than 1 CFU or when clinical "low concern" microorganisms appear in quantities greater than 100 CFU; GENCA and GESA, on the other hand, establish action when there is a growth of more than 10 CFU of "low concern" microorganisms ${ }^{(31,49)}$.

Key to safe clinical outcomes and improvement cycles are: running efficient processing; effective drying; storage in a clean, dry, ventilated place, without the valves and in a vertical position, when not using a controlled drying cabinet designed for horizontal positioning and with a cleanable structure, in association with the periodic evaluation of the practices carried out and training; as well as the use of validation and surveillance methods $s^{(31-32,34,50)}$.

Considering the evaluated articles, it was found that there was no consensus regarding the safe storage time and/or defined criteria for the use of endoscopes as essential. It appears, therefore, that this topic still constitutes a knowledge gap, requiring more research and evidence for its definition.

\section{Study limitations}

The scarcity of national studies on the storage of endoscopes contributed to the analysis being based only on the international reality. The adoption of eligibility criteria referring to processing methods used in Brazil was a strategy to reduce the disparity with the national reality.

The storage of endoscopes is a little explored subject, even internationally, given the guidelines of some gastroenterology societies, which remain with the uncertainty of this time under the justification of lack of high-quality evidence and others that do not mention any guidance in this regard. In this sense, the lack of robust production on the subject maintains a gap in knowledge in the nursing activity in endoscopy and indicates the direction so that investigations can and should be conducted, bringing answers that guide safe practices ${ }^{(2,35-36)}$.

\section{Contributions to the field of Nursing, Health or Public Policy}

The processing of endoscopes is a direct responsibility of nursing professionals, it requires rigor in the fulfillment of its numerous steps and an understanding of how their activities can change the health of patients.

It is essential for operating managers and professionals to know the safe time for the storage of post-processing endoscopes until their use, as well as the criteria that determine it, especially regarding the fulfillment of the steps and essential conditions for safe processing, which remain under discussion in the available guidelines. As an example of these steps, there is the use of automated cleaning, drying cabinets, rinsing with alcohol, among others. Thus, discussions about processing allow nurses to analyze and review not only storage, but what resources and conditions are necessary to establish it safely, considering the specifics of each service.

\section{CONCLUSIONS}

The storage of gastrointestinal endoscopes is an important step to maintain efficient processing, due to the risk of maintaining moisture inside the channels, which can contribute to recontamination, proliferation of microorganisms and biofilm formation in the equipment.

In the literature, the determination of safe storage time for the use of flexible gastrointestinal endoscopes after high-level disinfection did not present unified criteria. The indication of safe storage time, although controversial, reinforces the need for strict adherence to all stages of processing, especially drying and proper storage conditions, in addition to training professionals to perform the processing and handling of equipment after disinfection.

\section{ACKNOWLEDGMENT}

CNPq - National Council for Scientific and Technological Development.

\section{REFERÊNCIAS}

1. Rauwers AW, Holt AFVI, Buijs JG, Groot W, Hansen BE, Bruno MJ, et al. High prevalence rate of digestive tract bacteria in duodenoscopes: a nationwide study. Gut. 2018;67(9):1637-45. https://doi.org/10.1136/gutjnl-2017-315082

2. Day LW, Muthusamy VR, Collins J, Kushnir VM, Sawhney MS, Thosani NC, et al. Multisociety guideline on reprocessing flexible GI endoscopes and accessories. Gastrointest Endosc. 2021;93(1):11-33.e6. https://doi.org/10.1016/j.gie.2020.09.048

3. Ha J, Son BK. Current issues in duodenoscope-associated infections: now is the time to take action. Clin Endosc. $2015 ; 30 ; 48(5): 361-3$. https://doi.org/10.5946/ce.2015.48.5.361

4. Alfa MJ, Sepehri S, Olson N, Wald A. Establishing a clinically relevant bioburden benchmark: a quality indicator for adequate reprocessing and storage of flexible gastrointestinal endoscopes. Am J Infect Control. 2012;40(3):233-6. https://doi.org/10.1016/j.ajic.2011.02.023 
5. Saliou P, Le Bars H, Payan C, Narbonne V, Cholet F, Jézéquel J, et al. Measures to improve microbial quality surveillance of gastrointestinal endoscopes. Endoscopy. 2016;48(08):704-10. https://doi.org/10.1055/s-0042-107591

6. American National Standard Institute. ANSI/AAMI ST91:2015: flexible and semi-rigid endoscope processing in health care facilities [Internet]. Washington, DC: ANSI; 2015[cited 2020 Dec 15]. Available from: http://nascecme.com.br/2014/wp-content/uploads/2015/09/ ANSI-AAMI-ST91-Endoscopy-2015.pdf

7. Food and Drug Administration. Effective reprocessing of endoscopes used in endoscopic retrograde cholangiopancreatography (ERCP) procedures [Internet]. Silver Spring (MD): FDA; 2015[cited 2020 Dez 5]. Available from: https://regulatorydoctor.us/wp-content/ uploads/2015/07/Effective-Reprocessing-of-Endoscopes-Used-in-ERCP.pdf

8. Humphries RM, Yang S, Kim S, Muthusamy VR, Russell D, Trout AM, et al. Duodenoscope-related outbreak of a carbapenem-resistant klebsiella pneumoniae identified using advanced molecular diagnostics. Clin Infect Dis. 2017;65(7):1159-66. https://doi.org/10.1093/cid/cix527

9. Epstein L, Hunter JC, Arwady MA, Tsai V, Stein L, Gribogiannis M, et al. New Delhi metallo- $\beta$-lactamaseproducing carbapenem-resistant escherichia coli associated with exposure to duodenoscopes. JAMA. 2014;312(14):1447-55. https://doi.org/10.1001/jama.2014.12720

10. Rauwers AW, Troelstra A, Fluid AC, Wissink C, Loeve AJ, Vleggaar FP, et al. Independent root-cause analysis of contributing factors, including dismantling of 2 duodenoscopes, to investigate an outbreak of multidrug-resistant Klebsiella pneumoniae. Gastrointest Endosc. 2019;90(5):793-804. https://doi.org/10.1016/j.gie.2019.05.016

11. Carbonne A, Thiolet JM, Fournier S, Fortineau N, Kassis-Chikhani N, Boytchev I, et al. Control of a multi-hospital outbreak of KPC-producing klebsiella pneumoniae type 2 in France, September to October 2009. Euro Surveill. 2010; 2;15(48)19734. https://doi.org/10.2807/ ese.15.48.19734-en

12. Ofstead CL, Wetzler HP, Doyle EM, Rocco CK, Visrodia KH, Baron TH, et al. Persistent contamination on colonoscopes and gastroscopes detected by biologic cultures and rapid indicators despite reprocessing performed in accordance with guidelines. Am J Infect Control. 2015;43(8):794-801. https://doi.org/10.1016/j.ajic.2015.03.003

13. Ofstead CL, Heymann OL, Quick MR, Eiland JE, Wetzler HP. Residual moisture and waterborne pathogens inside flexible endoscopes: evidence from a multisite study of endoscope drying effectiveness. Am J Infect Control. 2018;46(6):689-96. https://doi.org/10.1016/j. ajic.2018.03.002

14. Rutala WA, Kanamori H, Sickbert- Bennet EE, Weber DJ. What's new in reprocessing endoscopes: are we going to ensure "the needs of the patient come first" by shifting from disinfection to sterilization?. Am J Infect Control. 2019;47S:A62-6. https://doi.org/10.1016/j. ajic.2019.01.017

15. Bajolet O, Ciocan D, Vallet C, Champs C, Vernet-Garnier V, Guillard T, et al. Gastroscopy-associated transmission of extended-spectrum betalactamase-producing pseudomonas aeruginosa. J Hosp Infect. 2013;83(4):341-3. https://doi.org/10.1016/j.jhin.2012.10.016

16. Naas T, Cuzon G, Babics A, Fortineau N, Boytchev I, Gayral F, et al. Endoscopy-associated transmission of carbapenem resistant Klebsiella pneumoniae producing KPC-2 beta-lactamase. J Antimicrob Chemother. 2010;65(6):1305-06. https://doi.org/10.1093/jac/dkq117

17. Alvarado CJ, Stolz SM, Maki DG. Nosocomial infections from contaminated endoscopes: a flawed automated endoscope washer: an investigation using molecular epidemiology. Am J Med. 1991;91(3B):S272-80. https://doi.org/10.1016/0002-9343(91)90381-7

18. Mendes KDS, Silveira RCCP, Galvão CM. Revisão integrativa: método de pesquisa para a incorporação de evidências na saúde e na enfermagem. Texto Contexto Enferm. 2008;17(4):758-64. https://doi.org/10.1590/S0104-07072008000400018

19. Araújo WCO. Recuperação da informação em saúde construção, modelos e estratégias. ConCl. 2020;3(2):100-34. https://doi.org/10.33467/ conci.v3i2.13447

20. Stetler CB, Morsi D, Rucki S, Broughton S, Corrigan B, Fitzgerald J, et al. Utilization-focused integrative reviews in a nursing service. Appl Nurs Res. 1998;11(4):195-206. https://doi.org/10.1016/S0897-1897(98)80329-7

21. Rejchrt S, Cermák P, Pavlatová L, Micková E, Bures J. Bacteriologic testing of endoscopes after high-level disinfection. Gastrointest Endosc. 2004;60(1):76-8. https://doi.org/10.1016/S0016-5107(04)01313-6

22. Grandval P, Hautefeuille G, Marchetti B, Pineau L, Laugier R. Evaluation of a storage cabinet for heat-sensitive endoscopes in a clinical setting. J Hosp Infect. 2013;84(1):71-6. https://doi.org/10.1016/j.jhin.2013.01.013

23. Osborne S, Reynolds S, George N, Lindemayer F, Gill A, Chalmers M. Challenging endoscopy reprocessing guidelines: a prospective study investigating the safe shelf life of flexible endoscopes in a tertiary gastroenterology unit. Endoscopy. 2007;39(9):825-30. https://doi. org/10.1055/s-2007-966766

24. Riley R, Beanland C, Bos H. Establishing the shelf life of flexible colonoscopes. Gastroenterol Nurs. 2002;25(3):114-9. https://doi. org/10.1097/00001610-200205000-00006

25. Ingram J, Gaines P, Kite R, Morgan M, Spurling S, Winsett RP. Evaluation of medically significant bacteria in colonoscopes after 8 weeks of shelf life in open air storage. Gastroenterol Nurs. 2013;36(2):106-11. https://doi.org/10.1097/SGA.0b013e318288c715

26. Scanlon P, Flaherty K, Reilly EA, Barth EG, Potter-Bynoe G, Cardini J, et al. Association between storage interval and contamination of reprocessed flexible endoscopes in a pediatric gastrointestinal procedural unit. Infect Control Hosp Epidemiol. 2017;38(2):131-5. https://doi. org/10.1017/ice.2016.260

27. Brock AS, Steed LL, Freeman J, Garry B, Malpas P, Cotton P. Endoscope storage time: assessment of microbial colonization up to 21 days after reprocessing. Gastrointest Endosc. 2015;81(5):1150-4. https://doi.org/10.1016/j.gie.2014.09.053 
28. Vergis AS, Thomson D, Pieroni P, Dhalla S. Reprocessing flexible gastrointestinal endoscopes after a period of disuse: is it necessary?. Endoscopy. 2007;39(8):737-9. https://doi.org/10.1055/s-2007-966644

29. Mallette KI, Pieroni P, Dhalla SS. Bacterial presence on flexible endoscopes vs time since disinfection. World J Gastrointest Endosc. 2018;10(1):51-5. https://doi.org/10.4253/wjge.v10.i1.51

30. Singh H, Duerksen DR, Schultz G, Reidy C, DeGagne P, Olson N, et al. Impact of cleaning monitoring combined with channel purge storage on elimination of escherichia coli and environmental bacteria from duodenoscopes. Gastrointest Endosc. 2018;88(2):292-302. https://doi. org/10.1016/j.gie.2018.02.018

31. Gastroenterological Society of Australia. Infection control in endoscopy: clinical update [Internet]. Victoria: GESA; 2010 [cited 2020 Jan 03]. Available from: http://www.genca.org/public/5/files/Endoscopy_infection_control\%20(low).pdf

32. Society of Gastroenterology Nurses and Associates. Standards of infection prevention in reprocessing flexible gastrointestinal endoscopes [Internet]. Chicago: SGNA; c2018[cited 2020 Dec 05]. Available from: https://www.sgna.org/Portals/0/SGNA\%20Standards\%20of\%20 infection\%20prevention\%20in\%20reprocessing_FINAL.pdf?ver=2018-11-16-084835-387

33. British Society of Gastroenterology Endoscopy. BSG guidance for decontamination of equipment for gastrointestinal endoscopy: the report of a working party of the British Society of Gastroenterology Endoscopy Committee [Internet]. 2020[cited 2020 Dec 23]. Available from: https://www.bsg.org.uk/wp-content/uploads/2021/02/BSG-Decontamination-guidance-2020-update.pdf

34. Public Health Agency of Canada. Infection prevention and control guideline for flexible gastrointestinal endoscopy and flexible bronchoscopy [Internet]. Nepean (ON): PHAC; 2010[cited 2020 Jan 06]. Available from: http://www.phac-aspc.gc.ca/nois-sinp/guide/endo/pdf/endo-eng.pdf

35. Beilenhoff U, Biering H, Blum R, Brljak J, Cimbro M, Dumonceau J-M, et al. Reprocessing of flexible endoscopes and endoscopic accessories used in gastrointestinal endoscopy: position statement of the european society of gastrointestinal endoscopy (ESGE) and european society of gastroenterology nurses and associates (ESGENA): Update 2018. Endoscopy. 2018;50(12):1205-34. https://doi.org/10.1055/a-0759-1629

36. Bashaw MA. Guideline implementation: processing flexible endoscopes. AORN J. 2016;104(3):225-36. https://doi.org/10.1016/j. aorn.2016.06.018

37. ECRI Institute. Top 10 health technology hazards for 2019 [Internet]. Plymouth Meeting (PA): ECRl; 2018 [cited 2020 Jan 02]. Available from: https://www.ecri.org/top-ten-tech-hazards/

38. Kovaleva J, Peters FTM, van der Mei HC, Degener JE. Transmission of infection by flexible gastrointestinal endoscopy and bronchoscopy. Clin Microbiol Rev. 2013;26(2):231-54. https://doi.org/10.1128/CMR.00085-12

39. Tian H, Sun J, Guo S, Zhu X, Fen H, Zhuang Y, et al. The effectiveness of drying on residual droplets, microorganisms, and biofilms in gastrointestinal endoscope reprocessing: a systematic review. Gastroenterol Res Pract. 2021:2021:6615357. https://doi.org/10.1155/2021/6615357

40. Azimirad M, Alebouyeh M, Sadeghi A, Khodamoradi E, Aghdaei H A, Alizadeh AHM, et al. Bioburden and transmission of pathogenic bacteria through elevator channel during endoscopic retrograde cholangiopancreatography: application of multiple-locus variable-number tandemrepeat analysis for characterization of clonal strains. Expert Rev Med Devices. 2019;16(5)413-20. https://doi.org/10.1080/17434440.2019.1604215

41. Benowitz I, Moulton-Meissner HA, Epstein L, Arduino MJ. The centers for disease control and prevention guidance on flexible gastrointestinal endoscopes: lessons learned from outbreaks, infection control. Gastrointest Endosc Clin N Am. 2020;30(4):723-33. https:// doi.org/10.1016/j.giec.2020.06.009

42. Suresh S, Pande M, Patel K, Mahometano LD, Romero LG, Barringer D, et al. Education, training, and knowledge of infection control among endoscopy technicians and nurses. Am J Infect Control. 2021;49(6):836-9. https://doi.org/10.1016/j.ajic.2021.01.010

43. Ofstead CL, Wetzler HP, Snyder AK, Horton RA. Endoscope reprocessing methods: a prospective study on the impact of human factors and automation. Gastroenterol Nurs. 2010;33(4):304-11. https://doi.org/10.1097/SGA.0b013e3181e9431a

44. Barakat MT, Huang RJ, Barnejee S. Comparison of automated and manual drying in the elimination of residual endoscope working channel fluid after reprocessing (with video). Gastrointest Endosc. 2019;89(1):124-32. https://doi.org/10.1016/j.gie.2018.08.033

45. Ofstead CL, Wetzler HP, Heymann OL, Johnson EA, Eiland JE, Shaw MJ. Longitudinal assessment of reprocessing effectiveness for colonoscopes and gastroscopes: results of visual inspections, biochemical markers, and microbial cultures. Am J Infect Control. 2017;45(2):e26-33. https://doi. org/10.1016/j.ajic.2016.10.017

46. Thaker AM, Kim S, Sedarat A, Watson RR, Muthusamy VR. Inspection of endoscope instrument channels after reprocessing using a prototype borescope. Gastrointest Endosc. 2018;88(4):612-9. https://doi.org/10.1016/j.gie.2018.04.2366

47. Costa DM, Lopes LKO, Hu H, Tipple AFV, Vickery K. Alcohol fixation of bacteria to surgical instruments increases cleaning difficulty and may contribute to sterilization inefficacy. Am J Infect Control. 2017;45(8):e81-6. https://doi.org/10.1016/j.ajic.2017.04.286

48. Perumpail RB, Marya NB, McGinty BL, Muthusamy VR. Endoscope reprocessing: comparison of drying effectiveness and microbial levels with an automated drying and storage cabinet with forced filtered air and a standard storage cabinet. Am J Infect Control. 2019;47(9):1083-9. https://doi.org/10.1016/j.ajic.2019.02.016

49. Department of Health and Human Services Collaboration. Duodenoscope surveillance sampling and culturing: reducing risks of infection [Internet]. [place unknown]: FDA; 2018[cited 2020 Jan 03]. Available from: https://www.fda.gov/downloads/MedicalDevices/ ProductsandMedicalProcedures/ReprocessingofReusableMedicalDevices/UCM597949.pdf

50. Gazdik MA, Coombs J, Burke JP, Lopansri BK. Comparison of two culture methods for use in assessing microbial contamination of duodenoscopes. J Clin Microbiol. 2016;54(2):312-6. https://doi.org/10.1128/JCM.02754-15 